\title{
KEWENANGAN BIDANG PERTANAHAN DALAM PELAKSANAAN OTONOMI DAERAH
}

\author{
Oleh: \\ Supriyanto
}

Fakultas Hukum Universitas Jenderal Soedirman Purwokerto

\begin{abstract}
Implementation of regional autonomy that is now almost up to enter the age of 10 years can reap a lot is said to have problems. One of the issues that must be addressed immediately is the problem of authority land. According to Law No. 5 th 1960, land is the task of the government (central government) while the provisions in Law No. 32 year 2004 field of land is the authority that has been submitted to the district / city. This course of action necessary for the second sincrinicity regulations are. Based on the approach to the legislation can be concluded that the authority has been the occurrence of land disputes as a result of dissincronicity regulations. For that they need to be made immediately the implementation of Tap MPR No. IX Th 2001 on Agrarian reform and the Management of Natural Resources in the Field of Land.
\end{abstract}

Kata Kunci: kewenangan, sinkronisasi

\section{A. Pendahuluan}

Pelaksanaan otonomi daerah yang hingga sekarang sudah memasuki implementasi tahun ke sepuluh, ada anggapan bahwa program nasional ini telah menimbulkan dampak negatif yang antara lain menimbulkan disintegrasi nasional dan ketegangan hubungan antara pemerintah dan daerah. Di samping itu, dianggap pula telah menimbulkan ketegangan atau konflik sosial di masyarakat, merebaknya korupsi, kolusi dan nepotisme (KKN) yang dilakukan elit politik, kesenjangan antar daerah dan jurang kemiskinan yang semakin dalam. ${ }^{1}$

Memperhatikan dari sekian banyak persoalan yang harus dibenahi oleh Pemerintah dalam pelaksanaan otonomi daerah adalah persoalan yang menyangkut masalah kewenangan pertanahan, terutama di daerah provinsi dan kabupaten/kota. Sesuai dengan Undang Undang Nomor 32 Tahun 2004 tentang Pemerintahan Daerah (Lembaran Negara RI Tahun 2004 No 125), dijelaskan kewenangan daerah diluar 6 (enam) kewenangan adalah merupakan kewenangan dari pemerintah daerah. Adapun kewenangan pemerintah (pusat) tersebut adalah meliputi: politik luar negeri, pertahanan, ke-

\footnotetext{
1 Hanif Nurcholis, 2005, Teori dan Praktek, Pemerintahan dan Otonomi Daerah , Jakarta : Grasindo, hlm. 12
}

amanan, yustisi, moneter dan fiscal nasional, agama. Hal ini artinya bahwa di luar enam kewenangan tersebut bidang pemerintahan yang wajib dilaksanakan oleh daerah provinsi, kabupaten/kota, antara lain adalah bidang pertanahan. Walaupun demikian perlu diperhatikan bahwa dalam proses peralihan wewenang ini tentunya tidak serta merta hanya melandaskan diri pada Undang Undang No 32 Th 2004 saja tetapi harus juga memperhatikan ketentuan perundangan lainnya yang berkaitan, yang dalam hal ini adalah Undang Undang No 5 Tahun 1960 tentang Peraturan Dasar PokokPokok Agraria atau biasa disebut dengan singkatan UUPA (LN 1960 No 104). Dalam UUPA antara lain dalam hubungannya dengan kewenangan pertanahan ada prinsip bahwa pertanahan merupakan wewenang dari pemerintah (pusat). ${ }^{2}$ Terkait dengan hal ini tentunya perlu adanya tindakan untuk mensinkronisasikan perundang-undangan tersebut sehingga tidak terjadi konflik kewenangan pertanahan.

Tugas bidang pertanahan dalam UU No. 32 Tahun 2004 seperti halnya menurut UU No. 22 Tahun 1999 dilaksanakan oleh dinas daerah atau lembaga teknis lainnya sesuai dengan ke-

\footnotetext{
2 Budi Harsono, 2005, Hukum Agraria Indonesia, Jilid I Hukum Tanah Nasional, Jakarta : Jambatan, hlm. 239
} 
butuhan daerah masing-masing. Namun setelah hampir tiga tahun Undang Undang Nomor 32 Tahun 2004 dilaksanakan, sampai sekarang pembagian kewenangan bidang pertanahan antara pemerintah (pusat) dan daerah belum juga usai. Pusat terkesan ingin menguasai semua kewenangan di bidang pertanahan, sementara itu pemerintah daerah juga ingin mendapat bagian urusan pertanahan.

Dalam perkembangannya, pemerintah justru mengeluarkan beberapa peraturan pelaksanaan ataupun petunjuk pelaksanaan yang membingungkan kabu-paten/kota. Pemerintah ternyata masih tetap mempertahankan Kantor Pertanah-an sebagai instansi vertikal dan mempertahankan kewenangan pertanahan sebagai kewenangan pemerintah, yaitu dengan di keluarkannya Keputusan Presiden Nomor 10 Tahun 2001 tentang Pelaksanaan Otonomi Daerah Di Bidang Pertanahan.

Memperhatikan Keputusan Presiden tersebut dapat ditarik kesimpulan bahwa kewenangan bidang pertanahan dibagi menjadi dua kewenangan, yang pertama, kewenangan dari pemerintah yang menyangkut wewenang di bidang hukum demi adanya unifikasi hukum dan ke-pastian hukum, dan yang kedua, kewenangan di bidang pemerintahan seperti tersebut dalam Pasal 11 ayat (2) UU No. 22 Tahun 1999 yang merupakan wewenang dari kabupaten/ kota, dengan demi-kian berdasarkan dua peraturan ter-sebut tidak satupun yang menyebut pemerin-tah daerah punya kewenangan pertanahan.

Dalam rangka lebih menegaskan kewenangan pemerintah di bidang pertanahan maka kemudian dikeluarkan Peraturan Presiden Nomor 10 Tahun 2006 tentang Badan Pertanahan Nasional (BPN), pada tanggal 11 April 2006. Pasal 2 Peraturan Presiden Nomor 10 Tahun 2006 menyebutkan BPN bertugas melaksanakan tugas pemerintah di bidang pertanahan secara nasional, regional dan sektoral, kemudian juga disebutkan BPN mempunyai 21 fungsi. Beberapa fungsi tersebut antara lain adalah pengaturan dan penetapan hak atas tanah, pembinaan dan pelayanan administrasi umum bidang pertanahan serta pelaksanaan penata gunaan tanah, reformasi agraria dan penataan wilayah-wilayah khusus.

Perihal pembagian kewenangan antara pemerintah, pemerintah provinsi dan pemerintah kabupaten/kota yang belum tuntas semenjak bergulirnya era otonomi kemudian memang pemerintah telah mengeluarkan Peraturan Pemerin-tah No 25 Th 2000 tentang Kewenangan Pemerintah dan Kewenangan Provinsi sebagai Daerah Otonom. namun dirasa tidak berjalan efektif. Oleh karena itu maka pemerintah pada tanggal 9 Juli 2007 menerbitkan Peraturan Pemerintah No. 38 Tahun 2007 tentang Pembagian Urusan Pemerintahan Antara Pemerintah, Pemerintah Daerah Provinsi dan Pe-merintah Daerah Kabupaten/Kota.

Berdasarkan latar belakang tersebut di atas maka permasalahan yang timbul adalah :

1. Bagaimanakah kewenangan bidang pertanahan dalam peraturan perundang-undangan di Indonesia?

2. Bagaimana mensinkronisasikan UU No 5 Th 1960 dengan UU No. 32 Tahun 2004 dalam hubungannya dengan kewenangan pertanahan?

B. Pembahasan

1. Kewenangan Bidang Pertanahan.

a. Kewenangan Pemerintah Pusat

Pengelolaan pertanahan di Indonesia didasarkan pada arah dan ke-bijakan dalam Pasal 33 ayat (3) Undang-undang Dasar 1945 di mana sampai dengan Amandemen yang ke IV secara redaksional tidak mengalami perubahan. Pasal 33 ayat (3) Undang Undang Dasar 1945 menyatakan bahwa : “ ... bumi dan air dan kekayaan alam yang terkandung di dalamnya dikuasai oleh negara dan dipergunakan untuk sebesar-besar kemakmuran rakyat". Berdasarkan landasan ini kemudian diundangkan Undang Undang No 5 Tahun 1960 tentang Peraturan Dasar Pokok Pokok Agraria yang di kemudian hari lebih dikenal dengan sebutan UUPA.

Pasal 2 UUPA menyebutkan:

1) Atas dasar ketentuan Pasal 33 ayat (3) UUD 1945 dan hal-hal sebagaimana dimaksud dalam Pasal 1 , bu- 
mi, air dan ruang angkasa termasuk kekayaan alam yang terkandung di dalamnya itu pada tingkatan tertinggi dikuasai oleh negara, sebagai organisasi kekuasaan seluruh rakyat;

2) Hak menguasai dari negara dalam ayat (1) pasal ini memberi wewenang:

a. Mengatur dan menyelenggarakan peruntukan, penggunaan, persediaan dan pemeliharaan bumi, air dan ruang angkasa tersebut;

b. Menentukan dan mengatur hubungan hukum antara orang-orang dengan bumi, air dan ruang angkasa;

c. Menentukan dan mengatur hubungan hukum antara orangorang dengan perbuatan-perbuatan hukum mengenai bu-mi, air dan ruang angkasa.

\section{b. Kewenangan Pemerintah Dae-rah Di Bidang Pertanahan}

Pasal 18 ayat 5 UUD 1945 merumuskan :

Pemerintahan daerah menjalankan otonomi seluas-luasnya, kecuali urusan pemerintahan yang oleh undangundang ditentukan sebagai urusan Pemerintah Pusat.

Pasal 2 Ayat (3) Undang Undang Nomor 5 Tahun 1960 (UUPA) menyebutkan:

Hak menguasai negara tersebut di atas pelaksanaannya dapat dikuasakan kepada daerah-daerah swatantra dan masyarakat-ma-syarakat hukum adat, sekedar diperlukan dan tidak bertentangan dengan kepentingan nasional, menurut ketentuan-ketentuan peraturan pemerintah.

Penjelasan Pasal 2 menyebutkan :

Dengan demikian maka pelimpahan wewenang untuk melaksanakan hak penguasaan dari negara atas tanah itu adalah merupakan medebewind. Segala sesuatunya akan diselenggarakan menurut keperluannya dan sudah barang tentu tidak boleh bertentangan dengan kepentingan nasional. Wewenang dalam bidang agraria dapat merupakan sumber keuangan bagi daerah itu.
Pasal 10 ayat (1) Undang Undang Nomor 32 Tahun 2004 tentang Pemerintahan Daerah menyebutkan :

Pemerintahan daerah menyelenggarakan urusan pemerintahan yang menjadi kewenangannya, kecuali urusan pemerintahan yang oleh undang undang ini ditentukan menjadi urusan pemerintah.

Sedangkan ayat 3 nya menyebutkan :

Urusan pemerintahan yang menjadi urusan pemerintah sebagaimana dimaksud pada ayat (1) meliputi :

a. Politik luar negeri;

b. Pertahanan;

c. Keamanan

d. Yustisi;

e. Moneter dan fiskal nasional; dan

f. Agama.

Pasal 14 ayat (1) huruf k menyebutkan :

Urusan wajib yang menjadi kewenangan pemerintahan daerah untuk kabupaten/kota merupakan urusan yang berskala kabupaten/ kota meliputi: huruf $k$. Pelayanan pertanahan.

Pasal 237 menyebutkan :

Semua ketentuan peraturan perundang-undangan yang berkaitan secara langsung dengan daerah otonom wajib mendasarkan dan menyesuaikan pengaturannya pada undang-undang ini.

Berdasarkan paparan peraturan perundang-undangan tersebut di atas maka dapat diuraikan pembahasan sebagai berikut. Dari ketentuan Pasal 2 UUPA yang merupakan pelaksanaan amanat Pasal 33 ayat (3) Undang-undang Dasar $1945,{ }^{3}$ dapat disimpulkan bahwa bumi, air dan kekayaan alam yang terkandung di dalamnya dikuasai oleh negara, artinya kekuasaan negara disini di jalankan oleh pemerintah berdasarkan hak yang disebut sebagai hak menguasai atas seluruh tanah yang ada di wilayah Republik Indonesia. Pengertian hak menguasai Negara dalam UUPA adalah memberi hak kepada Negara untuk meguasai tanah sementara kemudian mendistribusikannya sesuai de-

\footnotetext{
3 Maria SW Sumardjono, 2007, Pengaturan Hak Atas Tanah Beserta Bangunan, Jakarta : Kompas, hlm. 6
} 
ngan prinsip-prinsip kepentingan umum dan tidak merugikan kepentingan rakyat. ${ }^{4}$ Yang dikuasai dengan hak menguasai di sini baik berupa tanah hak (Hak masyarakat hukum adat, hutan-hutan, hak-hak perorangan berupa hak atas tanah dan sebagainya) maupun tanah negara. Hubungan antara negara dengan tanah yang ada bersifat sentralistis. Walaupun demikian, Pasal 2 ayat (4) menegaskan bahwa pelaksanaan hak menguasai ini dapat dikuasakan kepada daerah-daerah swatantra dan masyarakat-masyarakat hukum adat. Jadi walaupun pada asasnya tidak dapat diotonomkan tapi dapat di medebewind kan.

Secara teori, menurut Bagir Manan, medebewind adalah bagian dari desentralisasi, tidak ada perbedaan pokok antara otonomi dengan tugas pembantuan. Dalam tugas pembantuan terkandung unsur otonomi. ${ }^{5}$ Oleh karena itu Pemerintah Daerah mempunyai kebebasan untuk menentukan sendiri cara-cara melaksanakan tugas pembantuan. Tugas pembantuan sama halnya dengan otonomi, mengandung unsur "penyerahan" bukan "penugasan". Hanya bedanya kalau otonomi adalah penyerahan penuh sedangkan tugas pembantuan adalah penyerahan tidak penuh.

Apabila hal tersebut dihubungkan dengan pendapat Bagir Manan maka dapat disimpulkan bahwa ketentuan Pasal 2 ayat (4) UUPA memberikan peluang untuk di jadikan dasar hukum pemberian kewenangan pengelolaan pertanahan kepada daerah. Dengan demikian sebenarnya pengelolaan per-tanahan yang menurut Undang Undang Nomor 32 Tahun 2004 merupakan wewenang daerah mendapat penguatan dengan adanya ketentuan Pasal 2 ayat (3) UUPA. Di sini dapat disinyalir juga akan adanya kerancuan berfikir pembentuk Undang Undang tentang desentralisasi, otonomi dan tugas

\footnotetext{
4 Subekti Mahanani, 2001, Kedudukan UUPA 1960 dan Pengelolaan Sumber Daya Agraria Di Tengah Kapitalisasi Negara, Bandung : Akatiga, hlm. 25

${ }^{5}$ Bagir Manan, 1994,Hubungan Antara Pusat Dan Daerah Menurut UUD 1945, Jakarta : Pustaka Sinar Harapan, hlm. 180
}

pembantuan yang seolah-olah tidak ada hubungannya sama sekali. Berdasarkan Pasal 2 UUPA kemudian dikeluarkan Perpres Nomor 10 Tahun 2006 tentang Badan Pertanahan Nasional. Pasal 1 ayat 1 dan Pasal 2 Perpres tersebut menyebutkan :

Badan Pertanahan Nasional adalah Lembaga Pemerintah Non Departemen yang berada di bawah dan bertanggung jawab kepada Presiden. Badan Pertanahan Nasional mempunyai tugas melaksana-kan tugas pemerintahan di bidang pertanahan secara nasional, regional dan sektoral. Ketentuan ini makin menegaskan bahwa bidang pertanahan dalam politic will pemerintah pusat adalah merupakan wewenangnya bukan merupakan wewenang dari daerah kabupaten/kota.

Jadi dengan melandaskan diri pada Pasal 2 ayat (1) UUPA, Peraturan Presiden Nomor 10 Tahun 2006 yang kemudian di tindak lanjuti dengan Peraturan Kepala Badan Pertanahan Nasional Nomor 3 Tahun 2006 juncto Peraturan Kepala Badan Pertanahan Nasional Nomor 4 Tahun 2006 maka dapat dideskripsikan, bumi, air dan kekayaan alam yang terkandung di dalamnya dengan amanat Pasal 33 ayat (3) UUD 1945 yang kemudian ditindak lanjuti dalam Pasal 2 UUPA dikuasai oleh Negara. Prinsip inilah yang dijadikan dasar oleh pemerintah dalam me-nyelenggarakan pemerintahan yang berkaitan dengan masalah pertanahan. Pada intinya isi dari peraturan-peraturan tersebut menegaskan bahwa masalah pertanahan adalah merupakan wewenang pemerintah pusat. Wewenang disini dapat diartikan secara sederhana adalah kekuasaan untuk melakukan sesuatu tindakan hukum publik. ${ }^{6}$ Sedangkan kewenangan merupakan kumpulan dari wewenang-wewenang (rechtsbevoegdheden). ${ }^{7}$ Bidang pertanahan merupakan wewenang dari BPN yang mempunyai Kantor Wilayah di Provinsi (regional) dan

\footnotetext{
Safri Nugraha, 2005, Hukum Administrasi Negara, Jakarta : Fh UI, hlm. 38

7 SF Marbun, 1997, Peradilan Administrasi Negara dan Upaya Administrasi di Indonesia, Yogyakarta: Liberty, hlm. 154
} 
mempunyai Kantor Pertanahan di kabupaten/kota (sektoral).

Berdasarkan Pasal 2 ayat (4) UUPA, Pasal 14 huruf $k$ Undang Undang Nomor 32 Tahun 2006 dan Keputusan Presiden Nomor 34 Tahun 2003 maka menurut ketentuan Pasal 2 ayat (4) UUPA hak menguasai dari negara dapat di medebewind kan ke daerah swatantra. Kemudian berdasarkan Pasal 14 huruf k Undang Undang Nomor 32 Tahun 2004, urusan pelayanan pertanahan merupakan wewenang wajib dari kabupaten/ kota. Perincian wewenang pertanahan dari kabupaten/kota kemudian diatur dalam Keputusan Presiden Nomor 34 Tahun 2003. Jadi berdasarkan pelimpahan wewenang pertanahan dari Pemerintah tentunya kabupaten/kota secara yuridis sebenarnya mempunyai alasan yang kuat untuk mendapatkan otonomi di bidang pertanahan. Apalagi kemudian diperkuat lagi dengan dikeluarkannya Keputusan Presiden Nomor 34 Tahun 2003 yang lebih menegaskan tentang pembagian kewenangan di bidang pertanahan antara pusat dan daerah.

Walaupun demikian menurut Arie $\mathrm{S}$ Hutagalung dan Markus Gunawan, bidang pertanahan sebagai salah satu bidang pemerintahan yang wajib dilaksanakan oleh kabupaten/kota menurut Pasal 14 UU No 14 Tahun 2004, kewenangan dalam bidang pelayanan pertanahan tidak harus dicerna bahwa wewenang bidang tersebut secara utuh berada di kabupaten $/$ kota. $^{8}$

\section{Sinkronisasi UUPA dengan Undang Undang Nomor 32 Tahun 2004}

Istilah sinkronisasi berasal dari kata "sinkron" yang berarti serentak, sejalan, sesuai, selaras. Dengan demikian sinkronisasi berarti penyerentakan, penyesuaian, penyelarasan. ${ }^{9}$

Berdasarkan Pasal 33 ayat (3) Undang Undang Dasar 1945 jo Pasal 2 ayat (3) UUPA jo Pasal 3 Undang Undang Nomor 32 Tahun 2004

\footnotetext{
8 Arie S Hutagalung dan Markus Gunawan, 2008, Kewenangan Pemerintah Di Bidang Pertanahan, Jakarta : Raja Grafindo Persada

9 Anonimous, Kamus Pusat Pembinaan dan Pengembangan Bahasa, Jakarta : Balai Pustaka, 1996, hlm. 946
}

maka tujuan peraturan perundang-undangan tersebut secara substansial sebenarnya sama. Pemberian hak menguasai kepada Negara seperti yang dirumuskan dalam ketentu-an Pasal 2 ayat (3) UUPA digunakan untuk mencapai sebesar-besar kemakmuran rakyat dalam arti kebangsaan, kesejahteraan dan kemerdekaan dalam masyarakat dan Negara hukum Indonesia yang merdeka, berdaulat, adil dan makmur, sedangkan tujuan dari pemberian otonomi daerah menurut Pasal 2 ayat (3) Undang Undang Nomor 32 Tahun 2006 adalah menjalankan otonomi yang seluas-luasnya kecuali urusan pemerintahan yang menjadi urusan pemerintah, dengan tujuan untuk meningkatkan kesejahteraan masyarakat, pelayanan umum dan daya saing daerah.

Dilihat dari segi ini maka dapat ditarik kesimpulan bahwa antara UUPA dengan Undang Undang Nomor 32 Tahun 2004 mengandung tujuan yang sama atau dengan perkataan lain sudah sinkron. Hal ini hakikatnya sesuai dengan tujuan mendirikan negara sebagaimana telah diamanatkan dalam Pancasila dan juga dalam Pembukaan UUD 1945 yaitu untuk mewujudkan suatu keadilan sosial bagi seluruh rakyat Indonesia dan memajukan kesejahteraan umum dalam arti mencapai masyarakat yang adil dan makmur.

Kemudian, berdasarkan Pasal 2 ayat (1) UUPA pemerintah mengeluarkan Peraturan Presiden Nomor 10 Tahun 2006, Peraturan Kepala Badan Per-tanahan Nasional Nomor 3 Tahun 2006 jo Peraturan Kepala Badan Pertanahan Nasional Nomor 4 Tahun 2006 maka dapat dideskripsikan, bumi, air dan kekayaan alam yang terkandung di dalamnya dikuasai oleh Negara. Prinsip inilah yang dijadikan dasar oleh pemerintah dalam menyelenggarakan pemerintahan yang berkaitan dengan masalah pertanahan. Pada intinya isi dari peraturanperaturan tersebut menegaskan bahwa masalah pertanahan adalah merupakan wewenang pemerintah pusat. Wewenang disini dapat diartikan secara sederhana adalah kekuasaan untuk 
me-lakukan sesuatu tindakan hukum publik. ${ }^{10}$ Sedangkan kewenangan merupakan kumpulan dari wewenang-wewenang (rechtsbevoegdheden). ${ }^{11}$ Bidang pertanahan merupakan wewenang dari BPN yang mempunyai Kantor Wilayah di provinsi (regional) dan mempunyai Kantor Pertanahan di kabupaten/kota (sektoral).

Berdasarkan Pasal 2 ayat (4) UUPA, hak menguasai dari Negara dapat di medebewind ke daerah swatantra. Kemudian berdasarkan Pasal 14 huruf $k$ Undang Undang Nomor 32 Tahun 2004, urusan pelayanan pertanahan merupakan wewenang wajib dari kabupaten/ kota. Perincian wewenang pertanahan dari kabupaten/kota kemudian diatur dalam Keputusan Presiden Nomor 34 Tahun 2003. Jadi berdasarkan pelimpahan wewenang pertanahan dari pemerintah tentunya kabupaten/kota secara yuridis sebenarnya mempunyai alasan yang kuat untuk mendapatkan otonomi di bidang pertanahan. Apalagi kemudian diperkuat lagi dengan dikeluarkannya Keputusan Presiden Nomor 34 Tahun 2003 yang lebih menegaskan tentang pembagian kewenangan di bidang pertanahan antara pusat dan daerah.

Apabila hal tersebut di atas di-hubungkan dengan Pasal 2 ayat (1) UUPA, Peraturan Presiden Nomor 10 Tahun 2006 beserta peraturan pelak-sanaannya maka di bidang pertanahan telah terjadi dissinkronisasi peraturan perundang-undangan. Dipihak pemerintah menganggap bahwa wewenang pertanahannya secara yuridis adalah sudah sesuai dengan amanat Pasal 2 UUPA tetapi dilain pihak pemerintah daerah juga menganggap bahwa dengan berlakunya Undang Undang Nomor 22 Tahun 1999 yang kemudian direvisi dengan Undang Undang Nomor 32 Tahun 2004 maka secara yuridis pemerintah daerah mempunyai wewenang juga di bidang pertanahan.

Kondisi yang demikian dapat ter-jadi karena Undang Undang Pemerintahan Daerah hanya mengatur tanah dalam arti sempit, yaitu

\footnotetext{
10 Safri Nugraha, 2005, Hukum Administrasi Negara, Jakarta : Fh UI, hlm. 38

11 SF Marbun, 1997, Peradilan Administrasi Negara dan Upaya Administrasi di Indonesia, Yogyakarta: Liberty, hlm. 154
}

kewenangan pemanfaatan tanah dan pengelolaan bidang oleh kabupaten/kota, sedangkan me-nurut UUPA konsep tanah diartikan secara luas, meliputi penataan ruang, hak atas tanah, pendaftaran tanah, landreform dan lain sebagainya. Untuk itu maka urusan pertanahan yang dapat dilimpahkan dalam rangka otonomi daerah hanyalah urusan agraria (pertanian), sedangkan urusan kepemilikan tanah harus tetap berada pada kewenangan pusat. ${ }^{12}$

Menurut Maria SW Soemardjono, sejalan dengan reformasi maka paradigma penyelenggaraan pemerintahan telah bergeser dari sentralistis ke arah desentralisasi. ${ }^{13}$ Upaya untuk mengatasi kesenjangan ini dilakukan dengan melakukan revisi terhadap UUPA sekaligus mengkaji ulang sejumlah peraturan pelaksanaan UUPA dan undang-undang yang terkait dengan masalah pertanahan yang tidak konsisten dengan amanat dan semangat UUPA.

Pemberian wewenang pelayanan pertanahan kepada daerah kabupaten/kota yang mesti harus selalu diingat adalah masih dalam bingkai kesepakatan awal pembentukan negara kita yaitu Negara kesatuan, untuk itu maka kebebasan untuk mengatur dan mengurus bidang pertanahan akan tetap dilaksanakan dalam rangka kebijakan dasar dan pokok-pokok ketentuan hukum yang berlaku secara nasional. Sehubungan dengan itu maka otonomi jelas tidak diartikan sebagai penyerahan pengaturan dan pengurusan segala segi masalah pertanahan sepenuhnya kepada daerah kabupaten/kota, tetapi ada kewenangan-kewenangan yang bersifat pokok dan umum, serta pembinaan pada pusat terhadap pelaksanaan kewenangan otonomi tersebut oleh pemerintah daerah masingmasing. Dengan demikian, kendati daerah akan dan memang harus memperhatikan kepentingan dan aspirasi masyarakatnya yang beragam, tetapi akan tetap terjamin keserasian yang bersifat nasional.

Dalam rangka mengatasi permasalahan kewenangan pertanahan ini maka sebenarnya

\footnotetext{
12 Herman Sosongobeng, 2001, Struktur Organisasi Dalam Pengurusan Tanah Menurut UUPA dan Undang Undang No 22 Th 1999, Jakarta: Pustaka BPN, hlm. 8

13 Maria SW Soemardjono, 1997, Reorientasi Kebijakan Pertanahan Nasional, Jakarta: Kompas.
} 
pemerintah telah mengeluarkan Peraturan Pemerintah No 25 Th 2000 tentang Kewenangan Pemerintah dan Kewenangan Provinsi sebagai Daerah Otonom. Namun dalam praktek tidak berjalan efektif. Oleh karena itu maka pemerintah pada tanggal 9 Juli 2007 menerbitkan Peraturan Pemerintah No 38 Th 2007 tentang Pembagian Urusan Pemerintahan Antara Pemerintah, Pemerintah Daerah Provinsi dan Pemerintah Daerah Kabu-paten/Kota. Ditegaskan bahwa ke-wenangan dari pusat meliputi hukum, kebijakan, pedoman mengenai pemberian hak atas tanah, pendaftaran, landreform dalam bentuk undang-undang, peraturan pemerintah maupun keputusan presiden. Sementara itu kewenangan daerah cukup pada pelayanan masyarakat dan pelaksanaan kebijakan yang dapat dituangkan dalam bentuk peraturan daerah maupun keputusan kepala daerah.

Dengan keluarnya Peraturan Pemerintah No 38 Th 2007 tentu saja harapannya masalah kewenangan pertanahan ini dapat segera di atasi sehingga tidak menimbulkan polemik yang berkelanjutan yang tentu saja kontra produktif. Hal yang selalu harus diingat oleh para pembuat kebijakan bahwa telah jelas substansi dari tujuan pemberian kewenangan pertanahan tidak lain semata-mata untuk memberikan pelayanan yang sebaik-baiknya kepada masyarakat dengan cara yang seadil-adilnya sehingga angan-angan menuju masyarakat yang adil makmur dapat segera terrealisir. Hanya ada sedikit harapan kepada pemerintah bagaimana seandainya perihal pengaturan tentang pembagian kewenangan pertanahan ini tidak hanya diatur dengan peraturan pemerintah saja tetapi diatur dengan undang-undang karena polemik terjadi sumbernya berasal dari diundangkannya UU No 32 Th 2004 yang terkesan tidak sinkron dengan UUPA. Ditambahkan, selain itu juga materi yang diatur me-nyangkut kepentingan masyarakat umum.

Dengan telah terjadinya dissinkronisasi undang-undang tersebut di atas maka kemudian timbul pertanyaan, Undang-undang mana yang harus menyesuaikan, apakah UUPA yang harus menyesuaikan dengan UU No. 32 Tahun 2004 atau UU No. 32 Tahun 2004 yang harus me- nyesuaikan? Dalam hal ini menurut hemat penulis, perubahan fenomena penyelenggaraan pemerintahan dari sentralistis menjadi desentralisasi yang kemudian diikuti dengan pemberian otonomi yang luas kepada daerah kabupaten/kota, adalah merupakan kenyataan empiris dan normatif yang sudah semestinya dibarengi dengan perubahan UUPA. Apalagi seperti telah diketahui bahwa pada substansinya antara UUPA dengan Undang Undang Nomor 32 Tahun 2004 mempunyai tujuan yang sama melaksanakan amanat UUD 1945 yaitu menuju masyarakat yang adil dan makmur. Oleh karena itu maka tentunya UUPA yang diundangkan pada saat era sentralistis harus menyesuaikan dengan UU No. 32 Tahun 2004 yang merupakan produk di era desentalisasi. Hal ini juga sudah sesuai dengan ketentuan Pasal 237 UU No. 32 Tahun 2004 yang menyatakan bahwa semua ketentuan peraturan perundang-undangan yang berkaitan langsung dengan daerah otonom wajib mendasarkan dan menyesuaikan per-aturannya pada undang-undang ini.

Untuk itu diharapkan segera DPR RI bersama dengan Presiden RI mengatur lebih lanjut pelaksanaan pembaharuan agraria dan pengelolaan sumber daya alam serta mencabut, mengubah dan/atau mengganti semua undangundang dan peraturan pelaksanaannya sesuai dengan Tap MPR No IX Th 2001. Walaupun demikian harus tetap diingat bahwa pemberian kewenangan pertanahan kepada daerah kabupaten/kota tentu saja dalam bingkai Negara Kesatuan. Kecuali itu menurut Maria SW Soemardjono perlu ada kerelaan dan penegasan kewenangan pusat dan daerah, sehingga jelas pertanggung-jawabannya (akuntabilitas) masing-masing, utamanya dalam alokasi dan manajemen sumber-sumber agrarian/sumber daya alam, ${ }^{14}$ dapat dijadikan dasar dan juga acuan di dalam rangka mengadakan pembaharuan agraria.

\section{Penutup}

1. Simpulan

\footnotetext{
${ }^{14}$ Maria SW Sumardjono, Tanah , Dalam Perspektif Hak Ekonomi Sosial dan Budaya, Kompas, Jakarta, 2008, hlm 75.
} 
Berdasarkan hasil uraian dan pembahasan seperti tersebut di atas, maka dapat ditarik kesimpulan sebagai berikut:

a. Dalam bidang pertanahan antara UU No. 32 Tahun 2004 dengan UUPA telah terjadi dissinkronisasi.

b. Untuk menyikronkan antara UU No. 32 Th 2004 dengan UUPA itu maka perlu diadakan pembaharuan agraria sesuai dengan Tap MPR No IX Th 2001 dan pemberian kewenangan pertanahan tetap dalam bingkai Negara Kesatuan Republik Indonesia.

\section{Rekomendasi}

Dalam mengatasi permasalahan kewenangan pertanahan maka kebijakan yang di ambil harus selalu dalam bingkai Negara kesatuan dan sudah semestinya dalam bentuk undang-undang. Untuk itu diharapkan segera dibuatkan peraturan pelaksanaan Tap MPR NO IX Th 2001.

\section{Daftar Pustaka}

Anonimous. 1996. Kamus Pusat Pembinaan dan Pengembangan Bahasa. Jakarta: Balai Pustaka;

Harsono, Budi. 2005. Hukum Agraria Indonesia, Jilid I Hukum Tanah Nasional. Jakarta: Jambatan;

Hutagalung, Arie S, dan Markus Gunawan. 2008. Kewenangan Pemerintah Di Bidang Pertanahan. Jakarta: Raja Grafindo Persada;

Mahanani, Subekti. 2001. Kedudukan UUPA 1960 dan Pengelolaan Sumber Daya Agraria Di Tengah Kapitalisasi Negara. Bandung: Akatiga;

Manan, Bagir. 1994. Hubungan Antara Pusat Dan Daerah Menurut UUD 1945. Jakarta; Pustaka Sinar Harapan;

Marbun, SF. 1997. Peradilan Administrasi Negara dan Upaya Administrasi di Indonesia. Yogyakarta: Liberty;

Nugraha, Safri. 2005. Hukum Adminis-trasi Negara. Jakarta: FH UI;

Nurcholis, Hanif. 2005. Teori dan Praktek, Pemerintahan dan Otonomi Daerah. Jakarta: Grasindo;
Sosongobeng, Herman. 2001. Struktur Organisasi Dalam Pengurusan Tanah Menurut UUPA dan Undang Undang No 22 Th 1999. Jakarta: Pustaka BPN;

Sumardjono, Maria SW. 2007. Pengaturan Hak Atas Tanah Beserta Bangunan. Jakarta: Kompas;

2008. Tanah, Dalam Perspektif Hak Ekonomi Sosial dan Budaya. Jakarta: Kompas; 
Kewenangan Bidang Pertanahan

\section{(6)}

